\title{
CORRESPONDENCE
}

\section{Parkinsonian exasperation}

SIR, - Further to Robert Moss' letter (1 May, $\mathrm{p9}$,) it is of interest to consider the size of a primitive group of workers when liaison begins to become less effective and an administrator is appointed. Following Parkinson's work on committees (C N Parkinson, Parkinson's Law, 1958), experimental evidence from both scientific and socio-political groups seems to indicate that communication remains viable for groups of between 5 to 11 , with an optimum of 7 to 9 . Between 12 and 14 members, a part-time administrator is usually appointed, and the stage is set for the entry of centralisation.

One of the finest examples of misgrouping to be seen in public was the three day meeting between management and union staff, shown recently on BBC 1. Possibly unaware of Parkinson's work, the two scientists who convened the meeting set up a group of approximately 21 to 23 people, with predictable results. Despite the efforts on both sides to overcome the traditional divisions between management and unions, the lack of communication due to the group size increased exasperation to the point when people began to leave. Amazed by the rising irritation, the scientists sought to alleviate it by altering the seating arrangements (vide Parkinson on the shape and size of committee tables). Communication was restored only when the participants spontaneously divided into two groups of 10 to 12 each, both containing managers and unionists. It was difficult to determine who generated this split, given the highly condensed version of events presented, but it was certainly not the scientists.

Additional information to confirm or deny the hypothesis that smaller groups were suggested by the women trade unionists would be welcome.

Stage 3 of Parkinson's progression is considered by Moss to produce an 'intolerable' workload on the administrator, when he is burdened by 17 lines of communication
$\left(\mathrm{L}_{\mathrm{wi}}+\mathrm{L}_{\mathrm{ai}}\right)$. The above empirical analysis suggests that the maximum tolerable number of $\mathrm{L}_{\mathrm{wi}}+\mathrm{L}_{\mathrm{ai}}$ will be of the order of 10 to 12 . Yours faithfully,

Climatic Research Unit, University of East Anglia, Norwich, UK.

B M GRAY

\section{Feminist speculation}

SIR,- The thought-provoking discussion of the reasons why increased centralization is accompanied by decreased effectiveness presented by Robert Moss was both perceptive and pertinent. I should like to comment on an aspect which Dr. Moss appears to have overlooked. He states that the results of one study showed that "the production of scientific papers per man decreased as the organization increased in size." Was the production of scientific papers by women not affected? If not, what are the most likely reasons? Can one assume that women are less likely than men to be affected by this extension of Parkinson's Law?

The administrators described by Dr. Moss were apparently male, and it would be interesting to speculate on the outcome had some or all of the administrators been female. Yours faithfully,

C RIGBY

Aylmer,

Quebec, Canada.

\section{Erratum}

In Robert Moss's letter, 'Expanding on Parkinson's Law" (1 May) there was a typographical error. In stage four of his administrators' model, the equation $I_{w i}=W$ erroneously appeared as $1_{w i}=W^{2}+A$. Editor, Nature.

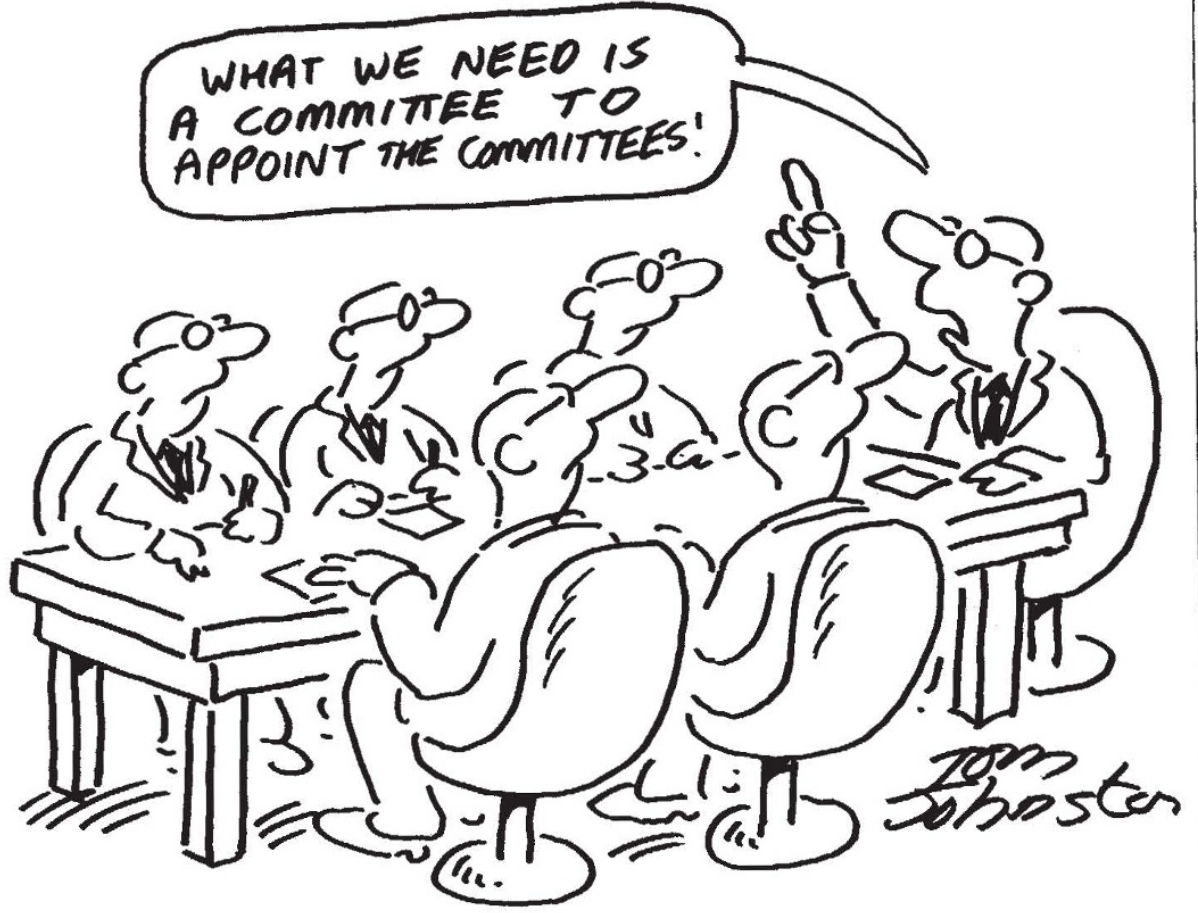

Smallpox and conservation

SIR, - It has been announced by the World Health Organization that smallpox now has been eliminated. The virus responsible for smallpox, an organism formerly abundant and widespread, has been systematically,

deliberately, and (as it appears) completely eradicated from all the natural systems of the world. With the exception of samples in a few laboratory 'zoos', it is extinct.

Those responsible for the demise of

smallpox will be praised universally, I am sure. But what an eloquent dilemma this presents to conservationists.

Statements of the conservation ethic normally include such clauses as "the preservation of species diversity" and "the protection of endangered species". What happens to those ideals in the aftermath of smallpox? Does the conservation ethic inevitably reduce to a pragmatic formula for the protection of the human species, or to a sentimental affection for the cute and the cuddly? Would anyone care to provide a satisfactory statement of what we really do mean when we speak with solemn and genuine concern about the protection of the natural world?

Yours faithfully,

Carleton University, JoHn MiddLeton, Ottawa, Canada.

\section{Making books cheaper}

SIR,-Your editorial, " Are Books Too Expensive?"' (24 April) is a reasonable and most welcome voice in the discussion of rising book prices. At The University of Chicago Press we have been giving a good deal of thought to measures that would decrease the costs of book production and therefore reduce the list price. These include: the publication of more original paperback books; printing some books from camera-ready typescript rather than setting all books in type; asking authors to forego some portion or royalty on the sale of a specified number of copies of books with smaller audiences; and simply not publishing certain classes of books such as the proceedings of symposia because their relevance is commonly limited over time.

The cooperation of those who write, distribute, review, and purchase books is essential to the success of any of these measures. Many scholars prefer to purchase paper-bound books or books that are printed from typescript because they are less expensive. Yet these same scholars baulk at the prospect that their own books might be published in such a fashion, chiefly because their colleagues see such methods as

characteristic of "second-rate" work or treatment. Some scholarly journals still refuse to review original paperbacks, and some libraries still refuse to buy them.

We as publishers must recognize that what is in the book must reach the intended audience and that the costs of "traditional" production may force the price of a book beyond the means of at least a fair proportion of the audience, particularly those who are students or younger faculty members, but we need and appreciate the cooperation of both authors and readers.

Yours faithfully, Susan E. Abrams

University of Chicago Press

Chicago, UK, US. 